\title{
MiNŐSÉGFEJLESZTÉSI TÖREKVÉSEK A PREVENCIÓ TERÜLETÉN A VILÁGBAN
}

\author{
FELVINCZI KATALIN \\ ELTE Pszichológiai Intézet
}

Világ-és Európa-szerte számos formában és szinten jelenik meg a prevenciós tevékenység, de annak egységes fogalomrendszere, tudományos bázisa nem kellőképpen kidolgozott, nincsenek egyértelmű elvárások azzal kapcsolatban sem, hogy a prevenciós szakembereknek milyen képzettséggel, milyen tudományos megalapozottsággal kell rendelkezniük. Az elmúlt 15 évben számos kezdeményezés fogalmazódott meg annak érdekében, hogy a prevenciós tevékenység szakmai megalapozottsága erősödjön, hogy a minőségi kritériumok váljanak ezen tevékenység szerves részévé, s hogy a szakterület nyerje el méltó helyét az alkalmazott tudományok körében. A tanulmány néhány olyan - elsősorban a drogprevenvenció területén jelentkező - kezdeményezés rövid bemutatását célozza, melyek az elmúlt években egyre erőteljesebben jelentkeznek és azzal az ígérettel kecsegtetnek, hogy ezen a területen is megjelenik egy feszes, tudományos igényủ gondolkodás, melynek eredményei a gyakorlati tevékenységben is tetten érhetővé válnak.

Kulcsszavakः drogprevenció, minőség, eredményesség, prevenciótudomány

There are many forms and levels of drug prevention activity around the world and in Europe, but its uniform conceptual framework and scientific basis are not well developed and there is no clear expectation as to what education professionals should have and what scientific background they need. Over the past 15 years, many initiatives have been taken to strengthen the professionalism of prevention activities, to make quality criteria an integral part of these activities, and to give the profession a prominent place in applied science. The study aims to briefly outline some of the initiatives that have emerged in recent years and with the promise that a strong, scientifically-minded thinking would appear in this field, the results of which will be translated into practical action.

Keywords: drug prevention, quality, effectiveness, prevention science

Levelező szerző: Felvinczi Katalin, ELTE Pszichológiai Intézet, 1075 Budapest, Kazinczy utca 23-27.

E-mail: felvinczi.katalin@ppk.elte.hu 


\section{Bevezetés}

$\mathrm{M}$

anapság a közgondolkodás szerves részének tekinthető, hogy semmilyen gyógyszernek minősülő anyagot nem fogyasztunk, ha az nem gyógyszertári forgalomban jelenik meg, s az is köztudott, hogy a gyógyszerkísérletek rengeteg időt, emberi és anyagi erőforrást igényelnek. Egy gyógyszer előállítása, piacra kerülése a gondolat ('igéretes vegyület) megszületéséhez képest mintegy 10-12 évet vesz igénybe, s a ráfordítások mintegy 2-2,5 Mrd dollárt tesznek ki (Mullin 2014). A humán intervenciók (pszichoterápia, népegészségügyi, prevenciós intervenciók) esetében nem ismeretes a beavatkozások előkészítésére irányuló előkészítő tevékenységek időtartama, költségtényezői. Az irodalmi hivatkozások tanúsága szerint az elemzések elsősorban a megvalósulás és az eredményesség egyes költségtényezőit veszik számba (pl. Honeycutt 2006; Institute of Medicine and National Research Council 2014), bár az utóbbi években egyre nagyobb hangsúly helyeződik az úgynevezett evidence-based megközelítésekre, valamint a standardizált eljárások mentén történő intervenciók fejlesztésére. Ezek a kezdeményezések ugyan nagyban hozzájárulnak a „softabb” humán intervenciók, így a prevenciós beavatkozások professzionalizálódásához, de a területen mind a mai napig hiányzik a szakmai/tudományos konszenzus abban a tekintetben, hogy egyes problémák kezelése során milyen megközelítéseket, intervenciókat szükséges használni a siker érdekében, valamint hogy ezek kimunkálása milyen időtartamot és költségeket igényel, vagyis hogy a szakmapolitikai tervezés során milyen volumenü forrásokat szükséges biztosítani. Jelen tanulmány általában a prevenciós tevékenység szakmaiságának erősödése területén tapasztalható fejlödéssel és/vagy fejlödési egyenetlenségekkel foglalkozik, de a bemutatott példák többsége a drogprobléma kezelésével, annak prevenciós célú megközelítésével hozható összefüggésbe. A drogprobléma vonatkozásában tapasztalható fejlemények nem vákuumban alakulnak, összefüggést mutatnak a népegészségügyi problémák egyéb területein tapasztalható fejlesztésekkel, különösen is az iskolai prevenció területén, ahol jellemzően az úgynevezett univerzális prevencióval, vagy az egészségfejlesztési megközelítésbe ágyazottan megjelenő preventív intervenciókkal találkozunk.

\section{A probléma magva - miért kell foglalkozni a minőségfejlesztéssel a prevenció területén?}

Közkeletü tévhit, hogy a prevencióhoz mindenki ért, annak célkitüzései és módszerei józan ésszel kikövetkeztethetőek, nem szükséges semmilyen speciális szakmai tudás ezen intervenciók kidolgozásához és megvalósításához. Ezekből a tévhitekből következhet, hogy sokan - még felelős döntéshozói helyzetben is - azt gondolják, hogy a büntetés és/vagy az elrettentés megfelelö módszer lehet pl. a kockázati viselkedések visszaszorításában (pl. elrettentő kampányok vagy szigorú büntetéseket kilátásba helyező büntetőpolitika a pszichoaktív szerhasználattal kapcsolatban), illetve hogy a helyes ismeretek szükségképpen helyes viselkedéshez fognak vezetni, ezért lenne érdemes felvilágosító előadásokat tartani gyerekeknek és felnőtteknek egyaránt a táplálkozási piramisról vagy a biztonsági öv használatáról (lásd pl.: Steiner 2014; Faggiano-Giannotta-Allara 2014). Noha számos kutatási tapasztalat megkérdőjelezi ezeket a vélekedéseket, és bizonyít- 
ja, hogy milyen jellemzői vannak a valóban eredményes prevenciós beavatkozásoknak (pl. Tobler 1997; Soole-Mazerolle-Rombouts 2005), a gondolat újra és újra megjelenik. Ugyanakkor ismert az a körülmény is, hogy a prevenciós beavatkozások hosszú távú hatásosságát (outcome, impact) nehéz meggyőzően bizonyítani. A prevenciós beavatkozások vonatkozásában az értékelés iránti igény főleg az elmúlt 30-35 évben jelentkezett pregnánsan; általában a szociális és egészségügyi programok értékelése a 20. század 30-as éveitől kezdve jelent meg tömeges mértékben. Ahogy ezt Hogan (2007: 3) Scrivenre hivatkozva írja: „Az értékelés egy fiatal diszciplína, de egy nagyon öreg gyakorlat." Az utóbbi évtizedekben az értékelő kutatások széles körben váltak elterjedtté a világ csaknem valamennyi országában (a történeti aspektusokkal kapcsolatban lásd: Hogan 2007; Calidoni-Lundberg 2006), bár mind a mai napig jelentős földrajzi és/vagy tematikai különbségek azonosíthatóak. Például Magyarországon a megfelelő módszertani igényességgel kivételezett programértékelések kisszámúak (Felvinczi 2009), nem tisztázott és egyértelmű a fogalomhasználat, különösen is a gyakorlati (terepen dolgozó) szakemberek körében, de még tudományos körökben is tapasztalható olykor fogalomzavar pl. a folyamatértékelés és monitorozás kifejezések tekintetében. A fogalmak tisztázása különösen fontos annak érdekében is, hogy érthető legyen, miként kapcsolódik össze a minőség fejlesztése iránti igény és az értékelő munka.

\section{Miért nehéz értékelni a prevenciós beavatkozásokat?}

A prevenciós beavatkozások értékelése több szempontból is problematikus lehet. Elöször is, a jelenleg megvalósítás alatt álló prevenciós intervenciók hatása általában, főleg, ha felnőttkori rizikómagatartások mérséklését célozzák, csak 10-15 év múlva éreztetik hatásukat (outcome, impact). A jelenben megvalósításra kerülő intervenciók kapcsán elsősorban az úgynevezett közvetítő változókban beálló változások mérésére van lehetőség; hogy ennek mennyire van értelme, az azon múlik, hogy rendelkezünk-e egy megbízható teoretikus modellel, amelyik valóban rá tud mutatni azokra a közbülső tényezőkre, amelyek megbízható előrejelzői a későbbi rizikómagatartásnak, következésképpen kedvező irányban történő befolyásolásuk valóban bejósló erővel bír a későbbi rizikómagatartások szempontjából. Ahhoz, hogy ebben az összefüggésrendszerben helyes következtetésre jussunk, kiterjedt longitudinális vizsgálatokra lenne szükség, melyek során végigkövethetőek lennének az interveniált populációban és a kontrollcsoportban zajló történések randomizált kontrollcsoportos $(\mathrm{RCT})^{1}$ vizsgálati elrendezések alkalmazásával. Másodsorban a prevenciós intervenciók egy jelentős hányada a populáció egészét célozza meg (univerzális prevenció, IOM 1994), ennélfogva rendkívül heterogén szociodemográfiai összetételü, életvezetésű populációról és annak alegységeiről beszélhetünk, továbbá a prevenciós intervenciók egy komplex élő (változó, fejlődő) rendszert céloznak meg, ahol az egyes alkotóelemek dinamikus kölcsönhatásban vannak egymással. Ezért, ha egy öszszetevő tekintetében változást érünk el, akkor a rendszer egészének müködése változhat, s eme komplexitás érdemi megragadására korlátozott eszköztár áll rendelkezésünkre. A drogprevenciós intervenciók értékelésével kapcsolatban számos útmutatás, kézikönyv látott napvilágot a 90-es évek második felében, ezek közül az egyik úttörő munka az

Jelen tudásunk alapján oksági következtetések levonására semmilyen más vizsgálati elrendezés nem jogosít fel bennünket, csak az RCT-k. 
1998-ban publikált Guidelines for the evaluation of drug prevention címmel az European Monitoring Centre for Drugs and Drug Addiction (EMCDDA, Kábítószer és Kábítószer-függőség Európai Megfigyelőközpontja) gondozásában megjelent kézikönyv volt (EMCDDA 1998), amelyik a projektek tervezésének és megvalósításának különböző állomásait végigkövetve fogalmazott meg ajánlásokat az intervenciók tervezői és az értékelő kutatásokban részt vevők számára. A kézikönyv 2012-es második, javított és bővített kiadása (EMCDDA 2012) az eredeti struktúrát megtartva, de azt újabb kutatási eredményekkel és tapasztalatokkal kiegészítve foglalkozik a témával.

\section{Miként haladhatjuk meg ezeket a nehézségeket - „történeti” elözmények}

A fentiekben felvillantott nehézségek meghaladását célozza számos olyan próbálkozás, mely nem megoldja, hanem megkerüli a problémát. Ilyen pl. az, amikor felismerve a prevenciós tevékenység összetett mivoltát, valamint a longitudinális kutatások költséges és az adatvédelmi szabályozások miatt egyre nehézkesebb jellegét, nem a hosszú távú eredmények mérésére, hanem a tervezés és a megvalósítás standardizálására és a közvetlen eredmények (vagy közvetítő változókban beálló változások) mérésére helyezik a hangsúlyt.

$\mathrm{Az}$ egyik ilyen első kezdeményezés a drogprevenciós beavatkozásokkal kapcsolatban a Kábítószer és Kábítószer-függőség Európai Megfigyelőközpontja (EMCDDA) által kiadott tanulmánykötet, mely a prevenciós tevékenység elméleti alapjait, bizonyos definíciós problémákat igyekezett tisztázni, valamint a prevenciós tevékenységgel kapcsolatos szakmai elvárásokat járta körül (Bübringer-Künzel 1998). Ez a tanulmánykötet egyben előremutató is volt, ugyanis előrevetítette az EDDRA adatbázis sajátosságait. Az adatbázisba elvileg csak értékelt programok kerülhettek be, de az értékeléssel kapcsolatos információ rendkívül szűkszavú volt, és az értékeléssel kapcsolatban egyértelmű módszertani elvárások sem fogalmazódtak meg.

\section{Adatbázisok, nyilvántartások}

A z EDDRA (Exchange on Drug Demand Reduction Action) adatbázis kialakítása az EMCDDA egyik nagyszabású fejlesztési projektje volt. Az adatbázis eredeti célja az volt, hogy az Európai Unió tagállamaiban elérhető keresletcsökkentési beavatkozásokat tegye széles körben ismertté és hozzáférhetővé. Elsősorban értékelt programokat kívánt bemutatni, de nem fogalmazott meg egyértelmü elvárásokat a programok tényleges értékelésével összefüggésben. Az EDDRA adatbázisba való bekerülés feltétele a müködés első 4-5 évében valójában csak a programok egységes szempontrendszer mentén történő leírása volt. A szempontrendszer viszonylag egyszerünek tekinthető, nagy vonalakban megegyezett azzal, amelyet a 2001-2005 között zajló, a prevenciós programok feltárását és teoretikus értékelését lehetővé tévő magyarországi kutatások is alkalmaztak (PaksiDemetrovics-Czakó 2002; Paksi-Demetrovics 2002, 2011). A fó cél az volt, hogy egységes struktúrában kerüljenek leírásra a keresletcsökkentési beavatkozások (prevenció, kezelés-ellátás, ártalomcsökkentés). Vagyis érdeklödtek az intervenció típusa, a megvalósítás színtere (iskola, munkahely, helyi közösség stb.), a célcsoport sajátosságai (életkor), az intervenció során megcélzott szerek (ha ez egyáltalán értelmezhető volt), a programok 
általános és specifikus célja(i), az ezeket megalapozó elméleti megfontolások, az egyes célkitűzésekhez tartozó indikátorok, valamint az elvégzett értékelés sajátosságai, az ennek során használt eszközök iránt.

Egy 2003-ban kiadásra került tanulmány (Burkhart-Matt 2003) kvalitatív elemzést hajtott végre 80 közösségi alapon szerveződő és az EDDRA adatbázisban található keresletcsökkentési intervención. Ennek tanúsága szerint a közösségi alapon szerveződő prevenciós intervenciók elsősorban az iskolai színtéren jelentek meg, főként információátadásra és az életvezetési készségek fejlesztésére koncentráltak, noha már ebben a periódusban is ismert volt a kutatási adatok alapján, hogy ezeknek a beavatkozásoknak meglehetősen korlátozott mértékủ hatásuk van a viselkedés változtatására. A programok/intervenciók egy másik azonosított jellegzetessége volt, hogy egyidejüleg számos célkitüzéssel és megközelítéssel dolgoztak, ez a körülmény nehézzé tette az eredményés folyamatindikátorok azonosítását, valamint az intervenciók struktúrába rendezett leírása is nehéznek bizonyult a legtöbb programgazda esetében. Az intervenciók hátterében meghúzódó elméleti modellek bemutatása is hiányzott az esetek többségében. A programgazdák sok esetben nem a tudományos elvárásoknak megfelelően definiálták a lebonyolított értékelési tevékenységet; saját minősítésük az értékelésre vonatkozóan különbözött a ténylegesen megvalósítottól. Ezen tapasztalatok alapján a kötet szerzői arra a következtetésre jutnak, hogy fokozott erőfeszítéseket kell tenni a képzés és továbbképzés terén annak érdekében, hogy valóban jó minőségü és eredményes intervenciók váljanak hozzáférhetővé. Az adatbázis bár a mai napig is hozzáférhető, annak használhatóságával kapcsolatban számos kritikai észrevétel fogalmazódott meg (a korábbiakban említetteken túlmenően is), nem adott ugyanis egyértelmű eligazítást a területen dolgozó szakemberek számára abban a tekintetben, hogy melyik program/intervenció lenne a legalkalmasabb számukra, ha egy már meglévő program alkalmazását tartják indokoltnak az adott nemzeti vagy regionális-helyi környezetben. Ezen problémák kiküszöbölése érdekében jött létre a jógyakorlatok (best parctice) portálja, amelyik egy másik aspektusból közelít a problémához.

\section{EMCDDA Best practice (jógyakorlatok) portal ${ }^{2}$}

Ez a kezdeményezés az értékelést helyezi a középpontba, vagyis az EDDRA adatbázisban található intervenciókat az eredményesség szempontjából csoportosítja. A portál többszempontos keresést tesz lehetővé, amelyben az érdeklődő kiválaszthatja, hogy milyen típusú intervenció (prevenció, kezelés, szociális reintergáció, ártalomcsökkentés), hogy milyen viselkedéses változásokat megcélzó intervenciók és milyen típusú bizonyítékok iránt érdeklődik. Jelen tanulmány szempontjából talán a legérdekesebb, hogy a bizonyítékoknak milyen szintjeit különböztetik meg. E tekintetben öt kategóriába sorolhatóak a beavatkozások: kedvező hatású (beneficial), feltételezhetően kedvező hatású (likely to be beneficial), kiegyensúlyozott, tehát kedvező és kedvezőtlen hatásai egyaránt vannak (trade off between benefits and harms), bizonyítottan nem eredményes (evidence of ineffectiveness), valamint ismeretlen eredményességü (unknown effevtiveness). A portál nemcsak azt teszi lehetővé, hogy az érdeklődő válogasson az itt található különböző

2 http://www.emcdda.europa.eu/html.cfm/index96523EN.html [Letöltve: 2019. 09. 30.] 
eredményességű programok között, hanem azt is, hogy tájékozódjon arról, hogy a különböző szintü bizonyítékokra milyen kutatási elrendezések révén lehet szert tenni.

A Jógyakorlatok portáljában rejlő potenciál még hangsúlyosabb kihasználását teszi lehetővé egy, a közelmúltba indult fejlesztés, mely hosszabb távon minden bizonynyal kiváltja - a sokat és sokak által kritizált - EDDRA adatbázist. Ez az úgynevezett Xchange adatbázis. ${ }^{3} \mathrm{Ez}$ a programok nyilvántartására létrehozott új fejlesztés harmonizál az EU drogstratégiájának megvalósítását támogató Tanácsi Következtetéssel (Council conclusions 2015), melynek célja támogatni a tagállamokat abban a törekvésükben, hogy minél inkább magas minőségü drogprevenciós beavatkozások valósuljanak meg. Ebbe a nyilvántartásba csak olyan programok kerülhetnek be, amelyek manualizáltak, ${ }^{4}$ és amelyek az értékelési kutatások ismeretében valóban bizonyítékon alapulónak tekinthetőek. A bizonyítékalapúság immár konszenzuális feltétele, hogy vagy randomizált kontrollcsoportos vizsgálatot, vagy kvázi kísérleti elrendezést, illetőleg megszakított idősoros elrendezést alkalmazó értékelő kutatások bizonyítsák az adott beavatkozás eredményességét. Továbbá elvárás még a programokkal kapcsolatban, hogy a fentiekben felsorolt vizsgálati elrendezések valamelyikét alkalmazó értékelő vizsgálat az adott beavatkozás eredményességét bizonyítsa.

A fentiekben röviden bemutatott fejlesztések fokozódó mértékben törekednek arra, hogy a programok/beavatkozások minél inkább egységes szempontrendszerben kerüljenek bemutatásra, továbbá hogy az eredményességre vonatkozóan egyértelmü állásfoglalás legyen megfogalmazható az átlátható és tudományosan megalapozott kutatási elrendezések mentén végzett értékelő munka eredményeképpen. Azonban a beavatkozások még oly transzparens és szakmailag megalapozott értékelése sem biztosítja, hogy az egyedi értékelési aktus érvényes megállapításokat tegyen egy hosszú távon futó programmal kapcsolatban, valamint az erőforrások szükössége és a drogprevenciós rendszerek nemzeti és/vagy helyi szinten eltérő müködése miatt előfordulhat, hogy az adott prevenciós szolgáltató nem egy már kifejlesztett és tesztelt programot fog adaptálni, hanem inkább saját fejlesztésbe fog. További nehezítő tényező, hogy számos, már futó program esetében nincs lehetőség a magas minőségü értékelő kutatások kivitelezésére. Ezek a kihívások hozzáadódnak a korábban már felsorolt tételekhez, melyek révén az értékelő munka komplex és problematikus jellegét próbáltuk szemléltetni.

\section{Tervezési útmutatók, szabályozó anyagok}

A szabályozó anyagok (módszertani levél, szakmai irányelv, protokoll, standardok) hivatottak a programfejlesztőket és programmegvalósítókat abban támogatni, hogy minél magasabb színvonalú és szakmai minőségü intervenciók kerüljenek megvalósításra. $\mathrm{Az}$ értékelő kutatások és a program/beavatkozás nyilvántartások használatával kapcsolatos tapasztalatok, valamint a fejlesztési projektek elszámoltathatóságával összefüggő fel-

http://www.emcdda.europa.eu/best-practice/xchange [Letöltve: 2019. 09. 30.]

4 A drogprevenciós programokat abban az esetben hívjuk manualizált programnak, amennyiben moduláris struktúrával rendelkeznek, és azok megvalósítására standardizált formában kerül sor. Meghatározott a tanórák vagy foglalkozások száma, sorrendje, tartalma, a foglalkozások és tevékenységek jellege, továbbá olyan kontextuális tényezők, mint a célcsoport összetétele, a programot megvalósító(k) személye, valamint a használandó segédanyagok. Ez a fajta kötöttség nagyban hozzájárul ahhoz, hogy értékelhető legyen a program. 
ismerések vezettek el ahhoz, hogy a kábítószer-probléma kezelését célzó beavatkozások (köztük hangsúlyosan a legszélesebb célcsoportot érintő prevenciós beavatkozások) terén is megjelenjenek a tervezési útmutatók és szabályozó anyagok. Ezek közül az első az úgynevezett PERK (Prevention Evaluation Resource Kit) volt (EMCDDA 2010).

Ez a tervezési eszköz végigvezeti a programfejlesztőket az intervenciós cikluson, oly módon, hogy az egyes állomások leírását követően bizonyos kérdésekre kell válaszolniuk, melyek eredményeképpen az új fejlesztés számos szempont egyidejü szem előtt tartása mellett korrekten leírhatóvá válik.

Fontos eleme ennek a tervezési segédeszköznek, hogy a különböző értékelési elemeket az intervenciófejlesztés immanens elemeként jeleníti meg. A tervezési eszköz fö „üzenete", hogy a gondosan megtervezett intervenció szükségképpen nagyobb eredményességgel is rendelkezik, valamint aláhúzza, hogy egy prevenciós intervenciónak szerves részét képezi az értékelés is, ezzel kívánja támogatni az értékelési kultúra minél szélesebb körben történő elterjesztését.

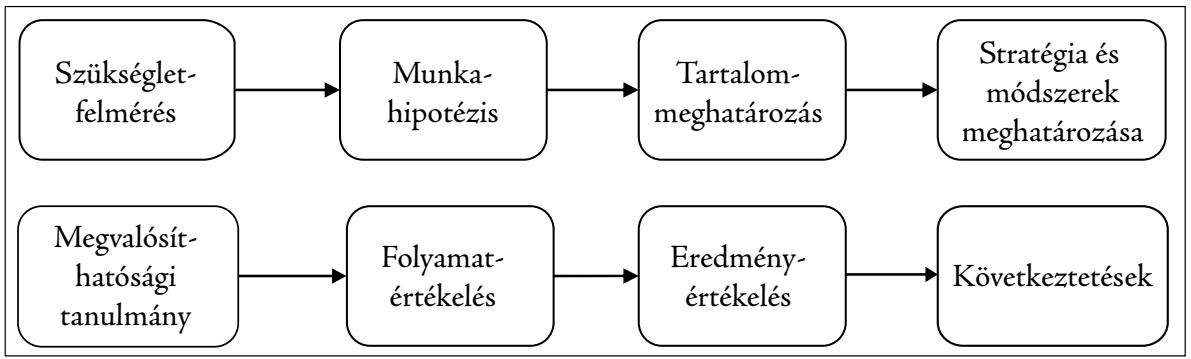

1. ábra: A PERK folyamatábrája

A tervezési eszközök és a minőségi elvárások még szorosabb összekapcsolását jeleníti meg az Európai Drogprevenciós Minőségi Standardok kimunkálását és gyakorlati alkalmazhatóságát elősegítő fejlesztés (EDPQS - http://prevention-standards.eu/standards/).

Ennek a fejlesztési törekvésnek az eredményeképpen többes funkciót szolgáló outputok keletkeztek.

- Kézikönyv (EMCDDA 2011), amelyik a programfejlesztőket segíti abban, hogy az intervenciós ciklus egyes elemeinek tartalmát szem előtt tartva minél jobb szakmai minőséggel rendelkező intervenciókat tudjanak kimunkálni.

- A Kézikönyv ugyanakkor arra is alkalmas, hogy az intervenciós ciklus egyes állomásaihoz tartozó elvárások teljesülését a programgazdák akár önképzési céllal, a döntéshozók pedig finanszírozási, fejlesztési döntéseiket megalapozandó tudják használni.

- Gyors útmutató (Quick Guide, EMCDDA 2013), ami összefoglalja a minőségi standardokkal kapcsolatos legfontosabb szempontokat, és gyors eligazodást biztosít mind a programok tervezőinek, mind pedig a szakpolitikai döntéshozóknak. Mindkét esetben a későbbi fejlesztések irányának meghatározása, illetve valamely konkrét intervenció szakmai megfelelőségének megítélése tekintetében tud ez az eszköz támpontokat adni.

Az Európai Drogprevenciós minőségi standardok is az intervenció életciklusához illeszkedve mutatják be az adott stádium szempontjából releváns tevékenységeket, eljárá- 


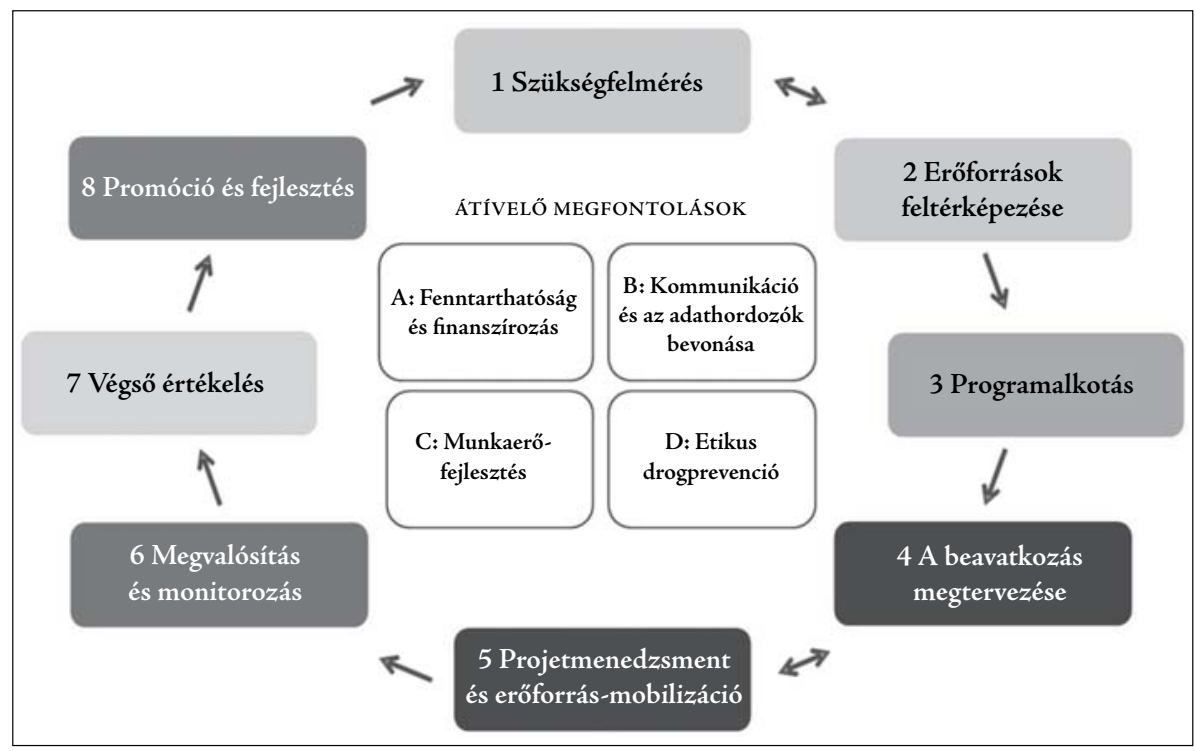

2. ábra: Az európai drogprevenciós minőségi standardok alapstruktúrája - a beavatkozás életciklusa

sokat, de az egyes állomások tartalmukban, irányultságukban különböznek a PERK-ben láthatóktól, mint ahogy ezt a későbbiekben még röviden érinteni fogjuk.

A PERK-hez képest új elemként jelennek meg az úgynevezett átívelő megfontolások, melyek általános sajátossága, hogy az itt megfogalmazódó szempontokat az intervenciós ciklus minden egyes állomásán szükséges figyelembe venni. Kiemelésre érdemes ezen átívelő megfontolások közül az etikai szempontok és a fenntarthatóság kérdése.

A fejlesztési kezdeményezés outputjai túlterjednek a fentiekben bemutatott néhány tételen (Kézikönyv, Gyors útmutató), de mindegyikre egyaránt érvényes, hogy egyfelől a fejlesztési folyamatot támogatják, másfelől pedig lehetővé teszik, hogy a már létező beavatkozások szakmai megfelelőségét ellenőrizzék. Ily módon alkalmas eszköznek tekinthetőek a tanúsítási folyamatban, vagyis ennek alapján egy megfelelő jogosítványokkal rendelkező szakmai szervezet (akkreditációs szervezet) el tudja bírálni a prevenciós beavatkozás szakmai minőségét.

\section{EQUS - Keresletcsökkentési minimum minőségi standardok}

Összhangban az Európai Unió 2009-2012-es periódusra vonatkozó kábítószerügyi akciótervével az Európai Bizottság megbízta a népegészségügyi és addikciós problémákkal foglalkozó svájci kutatóintézetet (ISFG), hogy dolgozzon ki egy olyan szakmai anyagot, ami a későbbiekben alkalmas lehet egy valamennyi tagállam egyetértését élvező útmutató kimunkáláshoz a keresletcsökkentési intervenciók területén. A szakmai anyag az intervenciók három csoportjával foglalkozik: prevenció, kezelés-ellátás-rehabilitáció, ártalomcsökkentés. A feladat ezen tevékenység során nem az volt, hogy új bizonyítékokat vagy új jógyakorlatokat dolgozzon ki azon területek vonatkozásában, ahol ezek még nem léteznek, hanem hogy feltárja, hogy jelenleg az Uniós tagállamokban az említett területeken milyen minőségi standardok léteznek, és azok milyen mértékben szolgál- 
ják a gyakorlatot. Ezen tapasztalatok alapján készült el a standardok vonatkozó listája, minden egyes beavatkozási terület vonatkozásában három szinten: i) az intervenciók, ii) a szervezetek és iii) a rendszer szintjén. A prevenciós terület vonatkozásában az EQUS projekt érdemi együttmüködést épített ki az EDPQS (Európai drogprevenciós minőségi standardok) kezdeményezéssel és a végső standardlistába a szakmai konszenzussal elfogadott standardok kerültek be. Az EQUS projekt nagy mértékben járult hozzá a végül 2015-ben elfogadott és kihirdetett Tanácsi Következtetésben foglaltakhoz (Council of the European Union 2015).

\section{International Standards on Drug Use Prevention $(2013,2018)^{5}$}

A kábítószer-probléma globális kihívásainak kezelésében meghatározó szerepet tölt be az ENSZ Kábítószerügyi és Bünügyi Hivatala, a UNODC (United Nations Office on Drugs and Crime). A szervezet reflektálva a minőségi beavatkozások iránt megnyilvánuló, egyre markánsabb igényre kezdeményezte a nemzetközi drogprevenciós standardok kidolgozását (UNODC 2013, 2018). A kiadvány összefoglaló jelleggel tárgyalja, hogy bizonyos beavatkozások, melyek az életkor tengelye mentén kerülnek bemutatásra (csecsemőkor - kisgyermekkor - serdülőkor - fiatal felnőttkor stb.), milyen eredményességi mutatókkal rendelkeznek, illetve hogy milyen szakpolitikai környezet szükséges ahhoz, hogy magas minőségü prevenciós tevékenység valósulhasson meg. Ez a munka is számos ponton reflektál az európai drogprevenciós minőségi standardokra, ugyanakkor arra kevésbé alkalmas, hogy az intervenciótervezési folyamatot támogassa.

A szabályozó anyagok általában három kategóriába sorolhatóak:

- Folyamatorientált szabályozók: ezek az eljárásrendekkel foglalkoznak, azokra vonatkozóan állapítanak meg kritériumokat. Például egy beavatkozás céltételezését, annak lehetséges tartalmi irányultságát nem szabják meg, de egyértelmű útmutatást tartalmaznak arra vonatkozólag, hogy minek az alapján lehet célokat kitüzni. Az EDPQS standardok ebbe a kategóriába tartoznak.

- Tartalomorientált szabályozók: ezek a beavatkozás tartalmára vonatkozóan fogalmaznak meg elvárásokat. Például meghatározzák, hogy egy prevenciós beavatkozásnak milyen célokat kell mindenképpen megvalósítania. Ebbe a kategóriába sorolható az UNODC által készített „Nemzetközi drogprevenciós standardok” címü összegző kiadvány.

- Vegyes profilú szabályozók, amelyek mind a tartalmi, mind pedig az eljárásrendi kérdésekben szakmai elvárásokat fogalmaznak meg, erre a szabályozó anyagra példa az Európai keresletcsökkentési minőségi standardok (EQUS) projekt keretében kimunkálásra került szempontrendszer (Uchtenhagen-Schaub 2012).

Az előzőekben röviden ismertetett tervezési útmutatók és szabályozó anyagok nagyban hozzájárultak a minőségi igény felkeltéséhez a drogprevenció területén, ugyanakkor egy alapvető kérdést nyitva hagytak. Igaz ugyan, hogy minden lehetséges ponton hangsúlyozzák az értékelés fontosságát, a programok tartalmának a megfogalmazásánál az evidencia alapú megközelítések alkalmazását, de az az elem még hiányzik a logikai teljesség eléréséhez, hogy ellenőrizhetővé váljon: vajon azok az intervenciók, amelyek akár az

5 https://www.unodc.org/documents/prevention/standards_180412.pdf [Letöltve: 2019. 12. 13.] 
EQUS, akár az EDPQS szempontrendszerben megfelelőnek bizonyultak, tényleg jobb hatásfokkal működő programok-e? Az értékelő kutatásoknak a jövőben erre az alapvető kérdésre kellene választ adniuk annak érdekében, hogy azt az fontos feltételezést bizonyítani lehessen, ami például a PERK alapvető üzenete is volt, hogy a gondosan tervezett prevenciós intervenciók jobb eredményre vezetnek a közvetlen és hosszú távú eredményesség tükrében.

\section{A szakemberek szakmai fejlődését támogató kezdeményezések}

$\mathrm{A} z$ EDDRA-ban elérhető közösségi alapú intervenciókat értékelő elemzés kapcsán a kutatók (Burkhart-Matt 2003) többek között arra a következtetésre jutottak, hogy az eredményesebb és egyben minőségi programok kimunkálása és megvalósítása érdekében a prevenciós szakemberek képzésére szükséges nagyobb hangsúlyt helyezni. Ezt a célt számos kutatásfejlesztési projekt szolgálta már az elmúlt években is.

Ezek közül az egyik a SPAN (Science for Prevention Academic Network - 20122014) projekt volt, mely az európai prevenciós egyetemi képzéseket és a prevenció területén dolgozó szakembereket kívánta feltérképezni, azzal a hosszú távú célkitűzéssel, hogy olyan egyetemi képzések jöjjenek létre, amelyek illeszkednek az európai felsőoktatási képzések rendszerébe, s melyek révén a prevenciós tevékenység szakmai színvonala érdemben növekszik. A projekt fókuszában általában a prevenciós tevékenység állt, nem szűkítette érdeklődését a drogprevenciós aktivitásokra. Noha számos hasznos közvetlen eredmény (pl. felsőoktatási kurzusok nyilvántartása, prevenciós tevékenység területén tevékenykedő felsőoktatási szakemberek jegyzéke - http://www.span-europe. eu/span) született a projekt eredményeképpen, de ezek nem terjedtek széles körben, és kevés történt az eredmények fenntarthatósága és továbbvitele érdekében. A projekt keretében létrejött adatbázisok további rendszerezése, a benne lévő információk validálása ugyanakkor mind a mai napig nagy lehetőségeket hordoz. A projekt egyik leglátványosabb és önmagán messze túlmutató eredménye az EUSPR (European Society for Prevention Research - Prevenciós kutatások európai társasága - http‡//euspr.org/ about-the-euspr/) megalakítása volt, mely szakmai társaság fó célkitűzése, hogy a prevenció különböző formáinak tudományos alapon történő szerveződését (tervezését és megvalósítását) támogassa, s hogy ily módon járuljon hozzá az egészségi állapot és jól-lét javulásához, valamint a területen jelentkező társadalmi egyenlőtlenségek leküzdéséhez.

Szintén a prevenciós tevékenység szakmai színvonalának javítását célozta az Általános prevenciós tananyag (Universal Prevention Curriculum, Sloboda et al. 2015) kidolgozása, aminek kimunkálásában az Applied Prevention Science International, Inc. játszotta a vezető szerepet. Ez olyan tananyag, melynek célja, hogy a területen dolgozó gyakorlati szakembereket és szakpolitikusokat tudományosan megalapozott ismeretekkel ruházza fel annak érdekében, hogy a prevenciós beavatkozások bizonyítékokon alapulóak legyenek, és következményesen azok eredményessége fokozódjon. A tananyag a prevenció tudományának (prevention science) aktuális felismeréseit és az utóbbi idők minőségi standardokkal kapcsolatos fejlesztéseit (EDPQS, Nemzetközi drogprevenciós standardok) inkorporálja. A tananyag hangsúlyozott figyelmet fordít arra, hogy a prevenció területén zajló tudományos fejlesztések eljussanak a gyakorlatban tevékenykedő szakemberekhez, ugyanis a tapasztalatok arra engednek következtetni, hogy a tudományos kutatások eredményei nem épülnek be a mindennapi prevenciós gyakorlatba. Ezért is tapasz- 
talják gyakran a kutatók, hogy még mind a mai napig olyan programok/beavatkozások kerülnek megvalósításra, amelyek tudottan nem eredményesek (pl. pusztán információközlésre szorítkoznak, vagy az elrettentés eszközeivel élnek). A tananyag kilenc részből áll, melyek egyfelől a prevenciós tevékenység multidiszciplináris alapjaiba (epidemiológia, pszichológia, a szerhasználat élettani és gyógyszertani vonatkozásai) vezetik be az olvasót, másfelől pedig a különböző színtereken (iskola, család, munkahely, helyi közösség stb.) folytatható prevenciós aktivitások tekintetében nyújtanak eligazítást. A tananyag felhasználása többes célt szolgál. A képzők képzését segítő kézikönyv a jövendőbeli prevenciós képzőket segíti, akik ennek alapján nemzeti vagy lokális kontextusban tudják az elsajátított ismereteket és módszereket továbbadni. Noha számos hasonló képzési anyag készült már az elmúlt évtizedekben, ennek az anyagnak a kiemelkedő fontossága abban ragadható meg, hogy mind Dél-Amerikában, mind Ázsiában széles körben próbálták elterjeszteni, s utóbb egy európai adaptációjára is sor került (UPC_Adapt - http:// upc-adapt.eu/project/). Jelen pillanatban nem állnak rendelkezésünkre értékelési adatok azzal kapcsolatban, hogy milyen változásokat ért el a tananyag a képzők és legfőképpen a végső célcsoport szintjén.

\section{Prevention science - a prevenció tudománya}

Ahogy ez a korábbiakban már említésre került, a prevenciós tevékenység tudományos megalapozottsága nem ismert széles körben. Ezért is lehetséges, hogy a laikusok és gyakran még a szakpolitikai döntéshozók is abban a hitben vannak, hogy ehhez a területhez mindenki ért, s nincsenek speciális, tudományosan megalapozott tudáselemek, amelyek útmutatást jelentenének a tevékenység megalapozottabb végzéséhez. A tudományterület első említése a 90-es évek második felére tehető, azóta intenzív fejlődés figyelhető meg párhuzamosan annak az igénynek az egyre hangsúlyosabbá válásával, hogy a tudományos kutatások eredményeit a gyakorlati prevenciós tevékenységbe lehessen átültetni. A prevenciótudomány nem jelent egy valódi új tudományterületet (sajátos teoretikus paradigmát, vizsgálati módszereket stb.), azonban a már létező tudományos megközelítéseket egységes rendszerbe foglalja, s egyértelműen a krónikus, nem fertőző megbetegedésekre (non-communicable disease) koncentrál. Egy multidiszciplináris megközelítésről beszélhetünk, mely a népegészségügyi problémák egy speciális csoportja esetében az etiológiát, a problémák elterjedtségének epidemiológiáját és azok mintázódását, a tudományosan megalapozott beavatkozástervezést vizsgálja (Sloboda-Petras 2014). A gondolkodás középpontjában az a felismerés áll, hogy a krónikus, nem fertőző megbetegedések hátterében oki jelentőséggel a viselkedés, az életmód sajátosságai állnak, s ezért a viselkedésváltozás tekintetében kell szakértelemmel rendelkezni annak érdekében, hogy eredményes beavatkozásokat tudjunk végrehajtani. A változás iránti igény az egyén, a helyi közösség és a magasabb szervezettségű társas-társadalmi tényezők szintjén egyaránt megjelenik. Tehát egy alkalmazott tudományról van szó, amelyik a már meglévő, ám gyakran elszigetelten létező tudományterületek integrálását kívánja megvalósítani oly módon, hogy figyelmét a népegészségügyi problémák egy speciális csoportjára irányítja és ennek a sajátos fókusznak megfelelően tárgyalja újra a már meglévő tudást. 


\section{Következtetések, kitekintés}

A fentiekben arra tettünk kísérletet, hogy áttekintsük, milyen elemekből is tevődik össze a prevenciós tevékenység szakmai fejlődését, tudományos megalapozottságát előmozdítani kívánó, manapság egyre inkább láthatóvá váló törekvés. Ahogy végigtekintünk az egyes elemeken, az a benyomásunk alakulhat ki, hogy itt valamilyen szerves fejlődésnek lehetünk tanúi; az egyes, jelen tanulmányban is bemutatott individuális elemek reflektálnak egymásra, a fejlődésnek mindig egy következő szintjére vezetnek. Az út az individuális beavatkozások értékelésétől egy komplett tudományág megjelenéséhez vezetett, s a prevenciótudomány immár a hosszú távú programalkotás szükségletét is megfogalmazza annak érdekében, hogy a megvalósításra kerülő prevenciós intervenciók valóban hasznosak legyenek, s hogy biztonsággal állíthassuk, hogy semmilyen iatrogén hatással nem bírnak (Faggiano-Giannotta-Allara 2014).

E nemzetközi áttekintést olvasva az olvasóban joggal merülhet fel a kérdés, hogy Magyarország hogyan helyezkedik el ebben a környezetben, vannak-e értékelő kutatások a prevenciós beavatkozásokkal kapcsolatban? Vajon nálunk csak a bizonyítottan eredményes programok kerülnek megvalósításra? Van a prevenciós beavatkozások minősítésének egy kialakult rendszere? Sajnos ezen kérdések tekintetében csak visszafogott és/vagy szomorú válaszokat adhatunk, ugyanis az elmúlt mintegy 9-10 évben semmilyen érdemi előrehaladás nem tapasztalható a prevenciós beavatkozások területén, sem azok számosságában és elérhetőségében, sem pedig szakmai színvonalukat illetően, ahogy ez pl. a Nemzeti Drogellenes Stratégia megvalósulásának félidős értékelése alkalmából készített kvalitatív vizsgálatból is kiviláglik (KCKT 2018). A prevenciós színtér helyzetével kapcsolatban 2009-ben az alábbi megfogalmazást tettük: „...a prevenciós programok finanszírozása továbbra is sok esetlegességet hordoz, minthogy ezen a területen mindeddig nem épült ki a normatív finanszírozás rendszere; az értékelési kultúra még mindig nem tekinthető kellő mértékben elterjedtnek, az értékelés iránti igény nem jelenik meg markánsan a szervezetek, programgazdák oldalán, ami érthető, hiszen a finanszírozási rendszer nem teszi sem kötelezővé, sem pedig lehetővé az értékelési elem kötelező jellegü beépítését; a programok akkreditációja, egyértelmű minőségi sztenderdek szerinti működtetése - noha ennek jogszabályi feltételei már megteremtődtek - még várat magára" (Felvinczi 2009). Sajnos még mindig.

\section{IRODALOM}

Burkhart, G. \& Matt, B. (2003) Community-based Drug Prevention Programmes from EDDRA, EMCDDA. http://mediatheque.lecrips.net/docs/PDF_GED/T02670.pdf, [Letöltve: 2019. 12. 13.]

BüHringer, G. \& Künzel, J.(1998) Evaluating Preventive Intervention in Europe: Evaluating Drug Prevention in the European Union. EMCDDA Scientific Monograph Series No. 2, 1997. Luxembourg: Office for Official Publications of the European Communities, 1998 ISBN 92-9168-050-8

Calidoni-Lundberg, F. (2006) Evaluation: Definitions, Methods and Models. Working Paper R2006:002. Swedish Institute for Growth Policy Studies. 
Council of the European Union (2015) Council Conclusions on the Implementation of the EU Action Plan on Drugs 2013-2016 Regarding Minimum Quality Standards in Drug Demand Reduction in the European Union.

EMCDDA (2010) Prevention and Evaluation Resources Kit (PERK) - A manual for Prevention Professionals. Luxembourg, Publications Office of the European Union. ISBN 978-92-9168-415-1, DOI: 10.2810/27577.

EMCDDA (2011) European Drug Prevention Quality Standards - A Manual for Prevention Professionals. Luxembourg, The Publications Office of the European Union. ISBN: 97892-9168-487-8, DOI: 10.2810/48879.

EMCDDA (2012) Guidelines for the Evaluation of DrugPprevention. A Manual for Programme Planners and Evaluators. Second edition Luxembourg, Publications Office of the European Union. ISBN 978-92-9168-499-1, DOI: 10.2810/51268.

EMCDDA (2013) European Drug Prevention Quality Standards: A Quick Guide. Luxembourg, Publications Office of the European Union. ISBN: 978-92-9168-665-0, DOI: $10.2810 / 15341$.

Faggiano, F., Giannotta, F \& \& Allara, E. (2014) Strengthening Prevention Science to Ensure Effectiveness of Intervention in Practice: Setting up an International Agenda. In: Z. Sloboda \& H. Petras (eds) Defining Prevention Science, Advances in Prevention Science. New York, Springer Science+Business Media. pp. 597-613. DOI: 10.1007/9781-4899-7424-2_26.

Felvinczi K. (2009) A kábítószer-probléma kezelésével összefüggő prevenciós tevékenység alakulása Magyarországon. In: Felvinczi K. \& Nyírády A. (eds) (2009) Drogpolitika számokban. Budapest, Nemzeti Drogmegelőzési Intézet; L'Harmattan. pp. 143-188. ISBN: 978-963-8833-60-0

Hogan, R. L. (2007) The Historical Development of Program Evaluation: Exploring the Past and Present. Online Journal of Workforce Education and Development, Vol. II. No. 4. (Fall)

Honeycutt, A. A., Clayton, L., Khavjou, O., Finkelstein, E. A., Prabhu, M., Blitstein, J. L., Douglas, W. E. \& Renaud J. M. (2006) Guide to Analyzing the Costeffectiveness of Community Public Health Prevention Approaches. March 2006. RTI Project Number 0208827.001

Institute of Medicine (1994) Reducing Risks for Mental Disorders: Frontiers for Preventive Intervention Research. In: P. J. Mrazek \& R. J. Haggerty (eds) Committee on Prevention of Mental Disorders. Washington DC National Academies Press (US); 1994. Available from: https://www.ncbi.nlm.nih.gov/books/NBK236319/ DOI: $10.17226 / 2139$.

Institute of Medicine and National Research Council (2014) Considerations in Applying Benefit-Cost Analysis to Preventive Interventions for Children, Youth, and Families: Workshop Summary. Washington DC, The National Academies Press. https://doi. org/10.17226/18708. [Letöltve: 2019. 12. 13.]

Kábítószerügyi Civil Koordinációs Testület (KCKT) (2018) A nemzeti drogellenes stratégia végrehajtásának félidös értékelése - A kábitószerügy területén dolgozó szervezetek és szakemberek percepciói alapján. https://docs.wixstatic.com/ugd/178071_4c5fac2f3bf140e6918fff 8fd77b179f.pdf [Letöltve: 2019. 12. 13.]

Mullin, R. (2014) Cost to Develop New Pharmaceutical Drug Now Exceeds \$2.5B. Chemical E Engineering News, November 20, 2014.

Paksi B. \& Demetrovics Zs. (2002) A drogprevenciós gyakorlat megismerése. A budapesti középiskolai drogprevenciós programok felmérése és értékelése. (Szakmai forrás sorozat 2.) Budapest, L'Harmattan. 
Paksi B. \& Demetrovics Zs. (2011, eds) Drogprevenció és egészségfejlesztés az iskolában. Budapest, NDI. L'Harmattan.

Paksi B., Demetrovics Zs. \& Czakó Á. (2002) Az iskolai drogprevenciós programok értékelése I-II. A programok teoretikus és szervezeti háttere, valamint a kivitelezésének vizsgálata. Addiktológia, 1. pp. 15-49.

Sloboda, Z., Hersch, R., David, S. B., Spoth, R., Ringwalt, Ch., Crano, W. \& Coatsworth, J. D. (2015) Introduction to Prevention Science, Trainer Manual. Colombo Plan International Centre for Credentialing and Education of Addiction Professionals (ICCE) Training Series. Universal Prevention Curriculum for Substance Use (UPC) Series 1 .

Sloboda Z. \& Petras H. (2014, eds) Defining Prevention Science. Advances in Prevention Science. New York, Springer Science+Business Media. DOI: 10.1007/978-1-48997424-2_26. https://www.issup.net/system/files/curriculum-downloads/Example\%20 UPC\%20Trainer\%20Manual.pdf [Letöltve: 2019. 12.13.]

Soole, D. W., Mazerolle, L. \& Rombouts, S. (2005) School Based Drug Prevention: A Systematic Review of The Effectiveness on Illict Drug Use. The Drug Policy Modelling Project Monograph Series. DPMP Monograph Series. Fitzroy: Turning Point Alcohol and Drug Centre. ISBN: 1740011686

Steiner, W. (2014) 5 Myths About Changing Behavior. Executive Coaching Concepts, November, 2014.

Tobler, N. S. (1997) Meta-analysis of Adolescent Drug Prevention Programs: Results of the 1993 Meta-analysis. In: William J. Bukoski (1997) Meta-Analysis of Drug Abuse Prevention Programs. NIDA Monograph 170. pp. 5-68. National Institute on Drug Abuse MIH Publication No. 97-4146

Uchtenhagen, A. \& Schaub, M. (2012) Minimum Quality Standards in Drug Demand Reduction EQUS. Final reort. JLS/2010/DPIP/PR/1023 - 30-CE-0336534/00-50

UNODC $(2013,2018)$ International Standards on Drug Use Prevention. Vienna, UNODC.

A cikk a Creative Commons Attribution 4.0 International License (https://creativecommons.org/licenses/ by/4.0/) feltételei szerint publikált Open Access közlemény, melynek szellemében a cikk bármilyen médiumban szabadon felhasználható, megosztható és újraközölhető, feltéve, hogy az eredeti szerző és a közlés helye, illetve a CC License linkje és az esetlegesen végrehajtott módosítások feltüntetésre kerülnek. (SID_1) 